OPEN ACCESS

Edited by:

Ling Wu,

Soochow University, China

Reviewed by:

Chao Shen,

Northwestern Polytechnical

University, China

Xiaobing Huang,

Hunan University of Arts and

Science, China

Renheng Wang,

Shenzhen University, China

*Correspondence:

Zhongliang Xiao

csustslb@csust.edu.cn

Specialty section

This article was submitted to

Electrochemistry,

a section of the journal

Frontiers in Chemistry

Received: 04 July 2020

Accepted: 22 July 2020

Published: 28 August 2020

Citation:

Song L, Du J, Xiao Z, Jiang P, Cao Z and Zhu H (2020) Research Progress

on the Surface of High-Nickel

Nickel-Cobalt-Manganese Ternary

Cathode Materials: A Mini Review.

Front. Chem. 8:761

doi: $10.3389 /$ fchem.2020.00761

\section{Research Progress on the Surface of High-Nickel Nickel-Cobalt- Manganese Ternary Cathode Materials: A Mini Review}

\author{
Liubin Song ${ }^{1}$, Jinlian Du ${ }^{1}$, Zhongliang Xiao ${ }^{1 *}$, Peng Jiang ${ }^{1}$, Zhong Cao ${ }^{1}$ and Huali Zhu ${ }^{2}$ \\ ${ }^{1}$ Hunan Provincial Key Laboratory of Materials Protection for Electric Power and Transportation, School of Chemistry and \\ Food Engineering, Changsha University of Science and Technology, Changsha, China, ${ }^{2}$ School of Physics and Electronic \\ Science, Changsha University of Science and Technology, Changsha, China
}

To address increasingly prominent energy problems, lithium-ion batteries have been widely developed. The high-nickel type nickel-cobalt-manganese (NCM) ternary cathode material has attracted attention because of its high energy density, but it has problems such as cation mixing. To address these issues, it is necessary to start from the surface and interface of the cathode material, explore the mechanism underlying the material's structural change and the occurrence of side reactions, and propose corresponding optimization schemes. This article reviews the defects caused by cation mixing and energy bands in high-nickel NCM ternary cathode materials. This review discusses the reasons why the core-shell structure has become an optimized high-nickel ternary cathode material in recent years and the research progress of core-shell materials. The synthesis method of high-nickel NCM ternary cathode material is summarized. A good theoretical basis for future experimental exploration is provided.

Keywords: lithium ion battery, high nickel type, ternary cathode material, surface, core-shell

\section{INTRODUCTION}

As environmental issues have become a major concern, reducing the use of fossil fuels has become a key issue. Lithium-ion batteries are the most commonly used energy storage devices due to their high energy density and long cycle life (Wang et al., 2020f; Zhang et al., 2020). The new energy industry powered by lithium-ion batteries has been greatly developed (Pant and Dolker, 2017; Barcellona and Piegari, 2020; Mossali et al., 2020; Wang et al., 2020d). However, fierce competition in this industry has brought about higher requirements for lithium-ion batteries (Zubi et al., 2018). The nature of the electrode material is the fundamental factor affecting the performance of the battery. Analyzing and optimizing the electrode material is an important approach to solving the bottleneck of the lithium ion battery (Lipu et al., 2018; Zhang et al., 2018).

$\mathrm{LiCoO}_{2}$ has good cycle stability in the cathode material of lithium batteries, but the actual capacity is low (Yang et al., 2018; Wang et al., 2020b). $\mathrm{LiMn}_{2} \mathrm{O}_{4}$ has excellent cycle performance but is prone to spinel phase degradation (Dai et al., 2012; Bhuvaneswari et al., 2019). $\mathrm{LiMnO}_{2}$ has good cycle performance but low preparation efficiency (Zheng et al., 2016; Zhou et al., 2016). $\mathrm{LiNiO}_{2}$ has high energy density but is prone to structural disorder (Liu et al., 2007; Deng et al., 2019). A 
layered lithium nickel-cobalt-manganese (NCM) oxide $\mathrm{LiNi}_{\mathrm{x}} \mathrm{Co}_{\mathrm{y}} \mathrm{Mn}_{\mathrm{z}} \mathrm{O}_{2}$ (LNCM) ternary cathode material with the combined advantages of $\mathrm{LiCoO}_{2}, \mathrm{LiNiO}_{2}$, and $\mathrm{LiMnO}_{2}$ has been generated (Park and Choi, 2018). In LNCM, the valences of nickel, cobalt, and manganese cations are usually $+2,+3$, and +4, respectively (Kang et al., 2006; Lin et al., 2014). Among them, +4 valence $\mathrm{Mn}$ guarantees structural stability, whereas +3 valence Co regulates cationic disorder and reduces surface energy (Garcia et al., 2017). The redox couple energy of $\mathrm{Ni}^{2+/ 4+}$ and $\mathrm{Co}^{3+/ 4+}$ can increase the battery's capacity (Lee et al., 2014). According to the crystal field theory, Ni mostly exists in the form of +2 valence. The radius of $\mathrm{Ni}^{2+}$ is close to the radius of $\mathrm{Li}^{+}$. Cation mixing easily occurs in high-nickel type NCM ternary cathode materials. $\mathrm{Ni}^{4+}$ has strong oxidizability; $\mathrm{Li}_{1-\mathrm{x}} \mathrm{NiO}_{2}$ formed after delithiation has poor thermal stability; $\mathrm{Ni}^{4+}$ easily reacts with organic electrolyte (Hong et al., 2012). The main lattice of the highly delithiated electrode surface releases oxygen, which reacts with the organic electrolyte (Abraham et al., 2002). The surface of the high-nickel material reacts with the external $\mathrm{CO}_{2}$ and $\mathrm{H}_{2} \mathrm{O}$ to form a lithium-containing compound (Liu et al., 2016; Gao et al., 2019).

This review starts with the surface and interface of the high-nickel NCM ternary cathode material. The causes of the defects in the material are analyzed. The core-shell structure that improves the performance of the high-nickel NCM ternary cathode material is explained. The methods of generating highnickel-type NCM ternary cathode material are mentioned.

\section{STUDY ON THE SURFACE AND INTERFACE STRUCTURE OF HIGH-NICKEL NICKEL-COBALT- MANGANESE TERNARY CATHODE MATERIALS}

The stable electrode surface and interface structure are the key factors that determine the quality of the battery. Structural defects and side reactions on the surface of the high-nickel NCM ternary positive material affect the transfer of electrons and the deintercalation of lithium ions, thereby affecting the performance of the battery (Wang et al., 2020c). The changes in the chemical properties of lithium-ion batteries in terms of surface and structure need to be elucidated.

\section{Surface Structure and Evolution of High-Nickel Cathode Materials}

The high-nickel NCM ternary cathode material has a- $\mathrm{NaFeO}_{2}$ structure; the space group is hexagonal $\mathrm{R}-3 \mathrm{~m} ; \mathrm{Li}^{+}$is embedded in the layered structure of transition metal and oxygen atoms and inserted and extracted in the 2D gap (Li et al., 2014; Liu Y. et al., 2019). In high-nickel type LNCM cathode materials, $\mathrm{Ni}^{2+}$ and $\mathrm{Li}^{+}$are prone to cation mixing (Yang et al., 2019b). Cation mixing shifts the hierarchical $\mathrm{R}-3 \mathrm{~m}$ space group to the tightly packed spinel Fm-3m space group. This tight structure leads to shorter ion spacing and larger interactions, making $\mathrm{Li}^{+}$ diffusion difficult (Zhang et al., 2017). Studies have suggested that structural changes occur on the surface of high nickel layered oxides (Li J. et al., 2020; Liu et al., 2020).

In layered $\mathrm{NMC}$ materials, $\mathrm{Li}^{+}$jumping and migration barriers are very sensitive to local structures (Van der Ven and Ceder, 2001; Kang and Ceder, 2006). Based on this, the diffusion rate of $\mathrm{Li}^{+}$in $\mathrm{LiNi}_{0.8} \mathrm{Mn}_{0.1} \mathrm{Co}_{0.1} \mathrm{O}_{2}$ (NMC811) is found to be the main reason for the structural change of the material. When the degree of lithiation deepens, the volume of a single positive electrode particle continues to shrink after delithiation. The lattice parameters change along with the material structure (Märker et al., 2019). Fu et al. (2014) found that with increasing number of lithium sources, the lattice parameters (a and c) and the thickness of the intercellular space decrease, and the $\mathrm{Li}^{+} / \mathrm{Ni}^{2+}$ mixed arrangement causes structural changes. Wang et al. (2017) studied the $\mathrm{LiNi}_{0.6} \mathrm{Co}_{0.2} \mathrm{Mn}_{0.2} \mathrm{O}_{2}$ (NMC622) material and found that spinel skeleton defects and a sharp drop in lattice parameter c cause lattice distortion. Moreover, the spinel structure causes the instability of the material surface and structure. Figure 1 shows the processing of high nickel NCM ternary cathode material, which is due to cation mixed discharge caused by structural changes (Wang et al., 2017). Many studies believe that heterogeneous ions can be inserted into the lattice through doping, thereby changing the bond energy and lattice parameters and suppressing the deterioration of the internal structure of the lattice (Binder et al., 2018; Yu et al., 2020).

\section{Mechanism of Surface Redox of High-Nickel Nickel-Cobalt-Manganese Ternary Cathode Material}

The thermal decomposition products of high-nickel LNCM cathode materials at high temperature may include the following: $\mathrm{Li}_{\mathrm{x}} \mathrm{Mn}_{2} \mathrm{O}_{4}, \mathrm{LiNiO}_{2},(\mathrm{NiO})_{\mathrm{x}}(\mathrm{MnO})_{\mathrm{y}}, \mathrm{CoO}, \mathrm{CoCO}_{3}, \mathrm{LiF}$, and various oxides of manganese, nickel, and cobalt (Wang et al., 2020a). The electronic structure of the active element in the transition metal layer is a factor that directly affects the redox reaction. Co and $\mathrm{Ni}$ have a +3 valence, and the energy band is $\left(t_{2 g}\right)^{6}\left(e_{g}\right)^{0}$, which is in a low spin state. The release of more than half of $\mathrm{Li}^{+}$ions from the layered $\mathrm{LiCoO}_{2}$ will cause $\mathrm{O}^{2-}$ $2 \mathrm{p}$ electron loss. The top of the $\mathrm{O}^{2-} 2 \mathrm{p}$ band overlaps with the $t_{2 \mathrm{~g}}$ band with $\mathrm{Co}^{3+/ 4+}$ redox activity, resulting in structural instability. The overlapping position of the $\mathrm{e}_{\mathrm{g}}$ band of $\mathrm{Ni}^{3+/ 4+}$ and the top of $\mathrm{O}^{2-} 2 \mathrm{p}$ band is lower than that of the $t_{2 g}$ band of $\mathrm{Co}^{3+/ 4+}$, indicating that the delocalization effect of $\mathrm{Ni}^{3+/ 4+}$ is smaller, the structure is more stable, and the reversible performance is better (Hou et al., 2017). The $\mathrm{e}_{\mathrm{g}}$ band of $\mathrm{Mn}$ does not overlap with $\mathrm{O}^{2-} 2 \mathrm{p}$, and the overlap of the $\mathrm{t}_{2 \mathrm{~g}}$ band and $\mathrm{O}^{2-} 2 \mathrm{p}$ is lower than that of $\mathrm{Co}^{3+/ 4+}$. Thus, the stability of $\mathrm{Mn}$ is higher. Julien et al. (2014) established a ternary $\mathrm{LiNi}_{\mathrm{y}} \mathrm{Mn}_{\mathrm{y}} \mathrm{Co}_{1-2 \mathrm{y}} \mathrm{O}_{2}$ oxide with better stability on the basis of $\mathrm{LiNiO}_{2}$ and $\mathrm{LiCoO}_{2}$ oxide structures (Julien et al., 2014).

Many studies have hoped to influence the energy band through doping and thereby improve the material's stability. Common doping approaches are as follows: anion doping: $\mathrm{F}^{-}$ (Zhao et al., 2019), Cation doping: $\mathrm{K}^{+}$(Liu Z. et al., 2019), $\mathrm{Al}^{3+}$ (Trease et al., 2016; Do et al., 2018), $\mathrm{Zr}^{4+}$ (Sivaprakash and Majumder, 2009), $\mathrm{Mg}^{2+}$ (Jin et al., 2019), $\mathrm{Ti}^{4+}$ (Zhang 


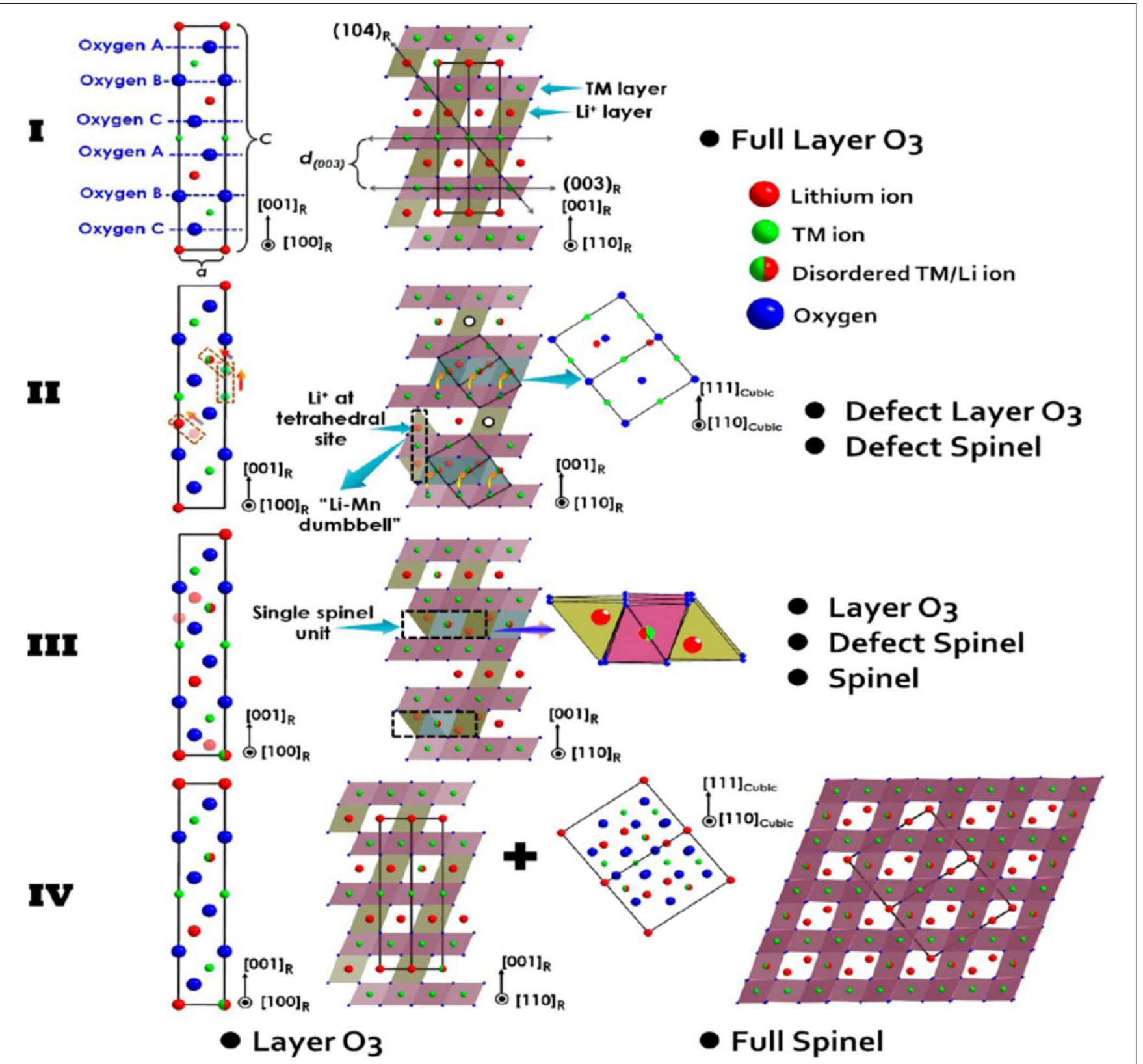

FIGURE 1 | High-nickel cathode material in four-stage microstructure of the atomic distribution and order of the schematic explanation.

et al., 2019), Co-doping: $\mathrm{Mn}^{4+}-\mathrm{PO}_{4}^{3-}$ (Qiu et al., 2019), and $\mathrm{Al}^{3+}-\mathrm{Mg}^{2+}$ (Woo et al., 2009). However, the doping of foreign elements can cause structural collapse because of the doping ions' inability to integrate into the layered structure.

\section{Side Reaction of High Nickel} Nickel-Cobalt-Manganese Ternary

\section{Cathode Material Interface Structure}

High-nickel LNCM cathode materials are prone to side reactions at the interface with the electrolyte. Side reactions and the products of such reactions can affect battery performance.
Usually, the decomposition of the electrolyte is as follows (Van Ree, 2020):

$$
\text { In general : } \mathrm{LiPF}_{6}(\mathrm{~s}) \leftrightarrow \mathrm{LiF}(\mathrm{s})+\mathrm{PF}_{5}(\mathrm{~g})
$$

In the presence of $\mathrm{H}_{2} \mathrm{O}: \mathrm{PF}_{5}+\mathrm{H}_{2} \mathrm{O} \rightarrow \mathrm{POF}_{3}+2 \mathrm{HF}$

$$
2 \mathrm{POF}_{3}+3 \mathrm{Li}_{2} \mathrm{O} \rightarrow 6 \mathrm{LiF} \downarrow+\mathrm{P}_{2} \mathrm{O}_{5} \downarrow\left(\text { or } \mathrm{Li}_{\mathrm{x}} \mathrm{POF}_{\mathrm{y}}\right)
$$

The high-nickel type LNCM positive electrode easily reacts with the surrounding environment due to its high surface reactivity (Jung et al., 2018). $\mathrm{LiF}, \mathrm{Li}_{2} \mathrm{CO}_{3}, \mathrm{LiOH}$, and other impurities are easily deposited on the interface between the active high 
nickel LNCM positive electrode and the electrolyte, thereby suppressing the diffusion of $\mathrm{Li}^{+}$and reducing the electrochemical performance. To effectively prevent the side reaction between the electrode and the electrolyte, coating modification is proposed, such as coating metal oxides: $\mathrm{Al}_{2} \mathrm{O}_{3}$ (Liao and Manthiram, 2015; Yan et al., 2016), $\mathrm{ZrO}_{2}$ (Yang et al., 2019a), MgO (Yoon et al., 2012), $\mathrm{ZnO}$ (Chang et al., 2010), lanthanide oxides: $\mathrm{La}_{4} \mathrm{NiLiO}_{8}$ (Li L. et al., 2020), phosphate: $\mathrm{AlPO}_{4}$ (Zhao et al., 2017), $\mathrm{Cu}_{3}\left(\mathrm{PO}_{4}\right)_{2}$ (Zhao et al., 2016), fluoride: $\mathrm{AlF}_{3}$ (Ding et al., 2017), transition metal oxide: $\mathrm{Li}_{2} \mathrm{ZrO}_{3}$ (Xu et al., 2016), multiple coating: $\mathrm{Li}_{2} \mathrm{TiO}_{3}^{-} \mathrm{Li}_{2} \mathrm{ZrO}_{3}$ ( $\mathrm{Li}$ J. et al., 2020), and $\mathrm{LiFePO}_{4}^{-} \mathrm{Al}_{2} \mathrm{O}_{3}$ (Seteni et al., 2017). The double modification method combines doping and coating, as follows: $\mathrm{Sr}$ doping- $\mathrm{LaMnO}_{3}$ coating ( $\mathrm{Li}$ et al., 2019), N doping-C coating (Nanthagopal et al., 2019), $\mathrm{Zr}$ doping- $\mathrm{ZrO}_{2}$ coating (Wang et al., 2020e), and Sn doping$\mathrm{Li}_{2} \mathrm{SnO}_{3}$ coating (Zhu et al., 2020).

\section{STUDY ON HIGH-NICKEL NICKEL-COBALT-MANGANESE TERNARY CATHODE MATERIALS WITH CORE-SHELL STRUCTURE}

The high-nickel type NCM cathode material is a combination of three transition metal elements. This material does not solve the defects of any one element. Although element doping, surface coating, and double modification can improve defects, these solutions only involve the simple processing of the body material and do not fundamentally solve the problem. Sun et al. (2005) extended the concept of cladding to the core shell and proposed the concept of using the core shell material for lithium ion batteries. The high-nickel nickelcobalt-manganese ternary cathode material with a core-shell structure has evolved from a common core-shell structure to a core-shell gradient structure, and finally, to a full gradient core-shell structure.

\section{Simple Core-Shell Structure}

In the high-nickel type NCM cathode material with a simple core-shell structure, a synergistic effect exists between the core and the shell. The core material has high specific capacity performance, and the shell material has structural and thermal stability. Sun et al. (2006b) used $\mathrm{Li}\left[\mathrm{Ni}_{0.8} \mathrm{Co}_{0.2}\right] \mathrm{O}_{2}$ with high specific capacity as the core and $\mathrm{Li}\left[\mathrm{Ni}_{0.5} \mathrm{Mn}_{0.5}\right] \mathrm{O}_{2}$ with high structural stability as the shell. They obtained a simple core-shell $\mathrm{Li}\left[\left(\mathrm{Ni}_{0.8} \mathrm{Co}_{0.2}\right)_{0.8}\left(\mathrm{Ni}_{0.5} \mathrm{Mn}_{0.5}\right)_{0.2}\right] \mathrm{O}_{2}$ cathode material. Compared with the $\mathrm{Li}\left[\mathrm{Ni}_{0.8} \mathrm{Co}_{0.2}\right] \mathrm{O}_{2}$ electrode, the capacity retention rate and thermal stability of the abovementioned synthesized cathode material are significantly improved. Shi et al. (2014) synthesized $\mathrm{Li}\left[\left(\mathrm{Ni}_{0.8} \mathrm{Co}_{0.1} \mathrm{Mn}_{0.1}\right)_{0.7}\left(\mathrm{Ni}_{0.45} \mathrm{Co}_{0.1} \mathrm{Mn}_{0.45}\right)_{0.3}\right] \mathrm{O}_{2}$ with $\left(\mathrm{Ni}_{0.8}\right.$ $\left.\mathrm{Co}_{0.1} \mathrm{Mn}_{0.1}\right)_{0.7}$ as the core and $\left(\mathrm{Ni}_{0.45} \mathrm{Co}_{0.1} \mathrm{Mn}_{0.45}\right)_{0.3}$ as the shell. The core-shell material cyclicity and thermal stability showed significant improvement. Jun et al. (2017) used $\mathrm{LiNiO}_{2}$ as the core and $\mathrm{Li}\left[\mathrm{Ni}_{0.8} \mathrm{Co}_{0.1} \mathrm{Mn}_{0.1}\right] \mathrm{O}_{2}$ as the shell to obtain $\mathrm{Li}\left[\mathrm{Ni}_{0.95} \mathrm{Co}_{0.025} \mathrm{Mn}_{0.025}\right] \mathrm{O}_{2}$ core-shell material, which provided excellent discharge capacity while exhibiting excellent cyclic performance. The simple core-shell structure effectively improves the performance of the battery, but the composition of the core and shell materials in this structure is significantly different, thereby producing a large interface resistance and hindering $\mathrm{Li}^{+}$diffusion. The high-temperature calcination process easily causes metal ion diffusion, resulting in structural changes in the material.

\section{Concentration Gradient Core-Shell Structure}

The concentration gradient core-shell structure is a new concept. It is proposed on the basis of a simple core-shell structure. A high-nickel-type NCM ternary material is coated with a shell material whose nickel concentration continuously decreases from the inside out. Liao et al. (2016) obtained the concentration gradient of the $\mathrm{LiNi}_{0.76} \mathrm{Co}_{0.1} \mathrm{Mn}_{0.14} \mathrm{O}_{2}$ cathode material from the double-shell $\left[\mathrm{Ni}_{0.9} \mathrm{Co}_{0.1}\right]_{0.4}\left[\mathrm{Ni}_{0.7} \mathrm{Co}_{0.1} \mathrm{Mn}_{0.2}\right]_{0.5}\left[\mathrm{Ni}_{0.5} \mathrm{Co}_{0 .} 1 \mathrm{Mn}_{0.4}\right]_{0.1}(\mathrm{OH})_{2}$ precursor's sintering, which significantly improves the capacity retention rate. Song et al. (2015) synthesized a concentration gradient $\mathrm{LiNi}_{0.5} \mathrm{Co}_{0.2} \mathrm{Mn}_{0.3} \mathrm{O}_{2}$ material. Figure 2 shows the principle of sintering a concentration gradient positive electrode material from a double-shell precursor (Song et al., 2015). The concentration gradient of the CG- $\mathrm{LiNi}_{0.7} \mathrm{Co}_{0.15} \mathrm{Mn}_{0.15} \mathrm{O}_{2}$ cathode material is prepared from the multilayer precursor, which effectively reduces side reactions and rapid $\mathrm{Li}^{+}$kinetics (Hou et al., 2018). With the concentration gradient of the $\mathrm{Li}_{1.2} \mathrm{Ni}_{0.13} \mathrm{Mn}_{0.54} \mathrm{Co}_{0.13} \mathrm{O}_{2}$ cathode material, the initial reversible capacity and capacity retention rate are improved (Ma et al., 2019). Liao and Manthiram (2015) used a concentration gradient $\left[\mathrm{Ni}_{0.2} \mathrm{Mn}_{0.8}\right]_{0.3}$ shell to encapsulate a high nickel $\left[\mathrm{Ni}_{0.8} \mathrm{Co}_{0.2}\right]_{0.7}$ core and coated $\mathrm{Al}_{2} \mathrm{O}_{3}$ on the surface of the shell to obtain a sample with better cyclic stability, rate performance, and thermal stability. The concentration gradient core-shell structure has a shell material with continuous concentration changes, which effectively reduces the interface resistance between the core and the shell and strengthens the synergistic effect between the core and the shell. However, the final surface of this structure still has a relatively high $\mathrm{Ni}$ content and a relatively low $\mathrm{Mn}$ content. When the high-temperature and high-voltage states are cycled for a long time at a high ratio, the electrochemical performance deteriorates.

\section{Full Concentration Gradient Core-Shell Structure}

The full concentration gradient core-shell material refers to the entire ternary precursor cathode material from the inside to the outside. The Ni ion content gradually decreases, and the $\mathrm{Mn}$ and $\mathrm{Co}$ ion contents increase continuously. The structure abandons the concept of having a clear core-shell interface and overcomes the problem of uneven coating of the shell layer or the large difference between the shell and core components. Ju et al. (2013) synthesized a full concentration gradient core-shell material from the center of the particle $(\mathrm{Ni}$ is $0.62-0.74 \mathrm{~mol} \%$; $\mathrm{Co}$ is $0.05 \mathrm{~mol} \%$ ) to the surface ( $\mathrm{Ni}$ is $0.48-0.62 \mathrm{~mol} \%$; Co is 0.18 mol\%). FCG-Li[ $\left.\mathrm{Ni}_{0.59} \mathrm{Co}_{0.16} \mathrm{Mn}_{0.25}\right] \mathrm{O}_{2}$ cathode material has a 


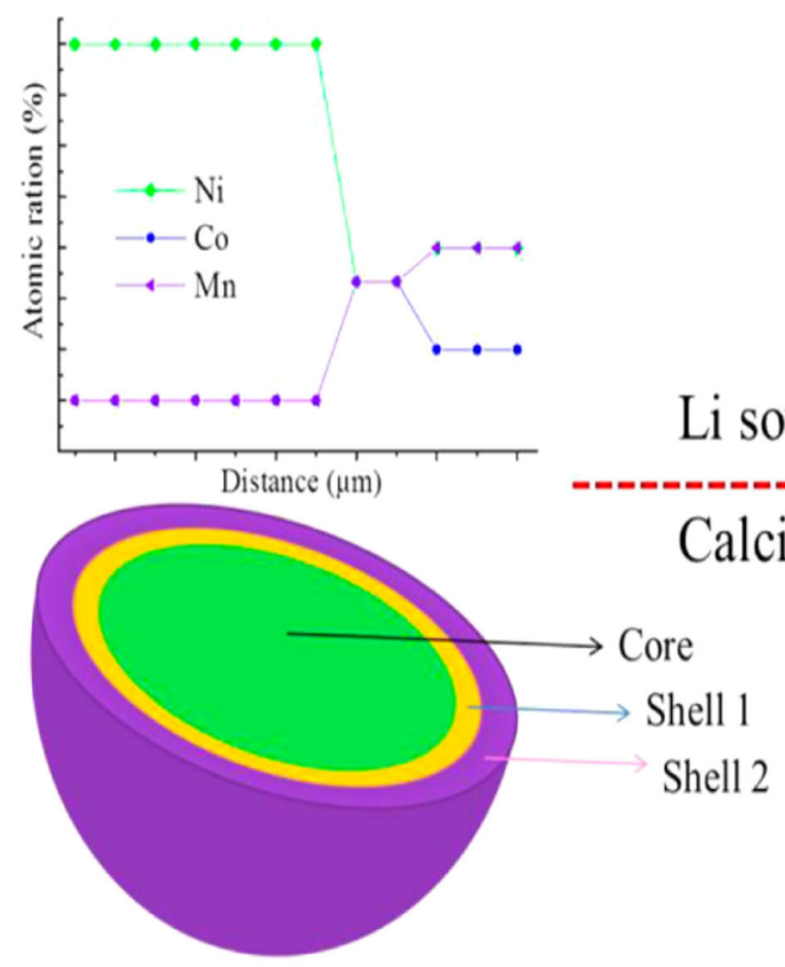

Double-shelled precursor

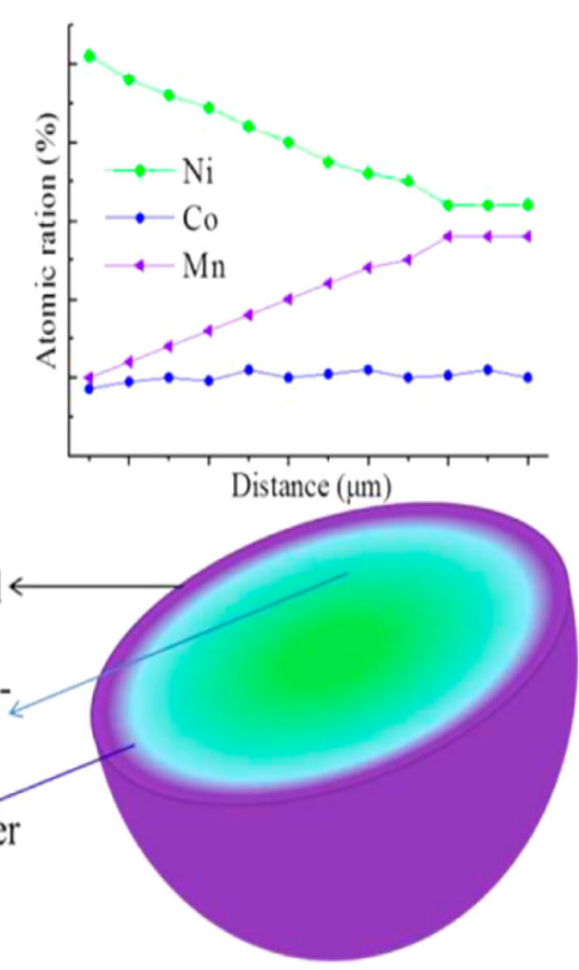

Novel structured oxide

FIGURE 2 | Schematic diagram of using a multi-shell precursor to control a positive electrode with a high nickel concentration gradient.

maximum discharge capacity of $188 \mathrm{mAh} \cdot \mathrm{g}^{-1}$. The FCG cathode material that gradually changes from $\mathrm{Li}\left[\mathrm{Ni}_{0.86} \mathrm{Co}_{0.07} \mathrm{Mn}_{0.07}\right] \mathrm{O}_{2}$ at the center of the particle to $\mathrm{Li}\left[\mathrm{Ni}_{0.67} \mathrm{Co}_{0.09} \mathrm{Mn}_{0.24}\right] \mathrm{O}_{2}$ at the surface shows high capacity performance (Noh et al., 2014). Full concentration gradient core-shell material $\mathrm{LiNi}_{0.7} \mathrm{Co}_{0.10} \mathrm{Mn}_{0.2} \mathrm{O}_{2}$ has higher cycle performance and high temperature stability and rate performance (Liang et al., 2015). The relative molar content of $\mathrm{Ni}$ in the full concentration gradient core-shell material $\mathrm{LiNi}_{0.8} \mathrm{Co}_{0.1} \mathrm{Mn}_{0.12}$ cathode material gradually decreases from $84 \%$ to $76 \%$, the relative molar content of Mn gradually increases, and the Co content shows a slow gradient variation. The capacity retention rate of this material after 100 cycles at $5 \mathrm{C}$ rate reaches 90\% (Jiang et al., 2019).

\section{METHOD FOR SYNTHESIZING HIGH-NICKEL NICKEL-COBALT-MANGANESE TERNARY CATHODE MATERIAL}

Different synthesis methods will affect the microstructure and electrochemical performance of the prepared materials. At present, the methods for preparing the high-nickel nickel-cobaltmanganese ternary cathode material for lithium ion batteries mainly include the co-precipitation and high-temperature solid phase methods.
A material synthesized by the co-precipitation method has a small and uniform particle size and is typically used for coating the high-nickel NCM ternary cathode material and for the synthesis of the core-shell structure. For example, the following are prepared by co-precipitation method: $\mathrm{LiNi}_{0.6} \mathrm{Mn}_{0.2} \mathrm{Co}_{0.2} \mathrm{O}_{2}$ (Ren et al., 2017), $\mathrm{LiNi}_{0.8} \mathrm{Mn}_{0.8} \mathrm{Co}_{0.1} \mathrm{O} @ \mathrm{Li}_{3} \mathrm{PO}_{4} @ \mathrm{PPy}$ (Chen S. et al., 2017), $\mathrm{Li}\left[\left(\mathrm{Ni}_{0.8} \mathrm{Co}_{0.1} \mathrm{Mn}_{0.1}\right)_{1-\mathrm{x}}\left(\mathrm{Ni}_{0.5} \mathrm{Mn}_{0.5}\right)_{\mathrm{X}}\right] \mathrm{O}_{2}$ (Sun et al., 2006a), $\mathrm{LiNi}_{0.8} \mathrm{Co}_{0.1} \mathrm{Mn}_{0.1} \mathrm{O}_{2} @ \mathrm{x}[\mathrm{Li}-\mathrm{Mn}-\mathrm{O}]$ (Li et al., 2018), and $\mathrm{LiNi}_{0.8} \mathrm{Co}_{0.1} \mathrm{Mn}_{0.1} \mathrm{O}_{2}$ @active material core-shell material (Su et al., 2019). High temperature solid phase method is typically used for doping modification, as follows: Ca doping $\mathrm{LiNi}_{0.8(1-\mathrm{x})} \mathrm{Co}_{0.1} \mathrm{Mn}_{0.1} \mathrm{Ca}_{0.8 \mathrm{x}} \mathrm{O}_{2}$ (Chen M. et al., 2017), Mn doping $\mathrm{LiNi}_{0.82-\mathrm{x}} \mathrm{Co}_{0.12-\mathrm{x}} \mathrm{Mn}_{0.06+2 \mathrm{x}} \mathrm{O}_{2}$ (Cho et al., 2018), and Mo doping $\mathrm{LiNi}_{0.6} \mathrm{Co}_{0.2} \mathrm{Mn}_{0.2} \mathrm{O}_{2}$ (Xue et al., 2018). Sol-gel, hydrothermal, and spray drying methods, as well as other preparation methods, are also available. Sol-gel method is used to prepare $\gamma-\mathrm{Al}_{2} \mathrm{O}_{3}$-coated $\mathrm{NCM} 622$ (Wu et al., 2019) and tungsten oxide-coated NCM-811 (Becker et al., 2019). $\mathrm{LiNi}_{0.7} \mathrm{Co}_{0.15} \mathrm{Mn}_{0.15} \mathrm{O}_{2}$ is prepared by hydrothermal method (Tian et al., 2015). NCM811 is prepared by spray drying (Huang et al., 2019).

\section{CONCLUSIONS}

For high-nickel-type LNCM ternary cathode battery materials, improving energy density, cycle performance, and thermal stability are the focus of future research. The energy band and 
structure from the material surface and interface need to be analyzed to come up with an improved optimization plan.

High-nickel type NCM ternary cathode materials easily phase change and release oxygen due to the high nickel content. Traditional modification does not essentially solve the structural problems. The core-shell structure promotes the development of high-nickel NCM ternary cathode materials. The high-nickel NCM ternary material with core-shell structure is usually composed of a high-nickel core and a high-manganese shell, which effectively inhibit phase transition and improve cycle performance and thermal stability. The high energy density of the cathode material is ensured. In the coreshell interface of the simple core-shell, the transition metal components cause structural mismatch due to mutations. The final surface of the concentration gradient core-shell still has high $\mathrm{Ni}$ content and low Mn content. Under high-strength electrochemical conditions, the structure remains unstable. The full concentration gradient core-shell structure abandons

\section{REFERENCES}

Abraham, D. P., Twesten, R. D., Balasubramanian, M., Petrov, I., McBreen, J., and Amine, K. (2002). Surface changes on $\mathrm{LiNi}_{0.8} \mathrm{Co}_{0.2} \mathrm{O}_{2}$ particles during testing of high-power lithium-ion cells. Electrochem. Commun. 4, 620-625. doi: 10.1016/S1388-2481(02)00388-0

Barcellona, S., and Piegari, L. (2020). Effect of current on cycle aging of lithium ion batteries. J. Energy Storage 29:101310. doi: 10.1016/j.est.2020.101310

Becker, D., Börner, M., Nölle, R., Diehl, M., Klein, S., Rodehorst, U. C., et al. (2019). Surface modification of Ni-rich $\mathrm{LiNi}_{0.8} \mathrm{Co}_{0.1} \mathrm{Mn}_{0.1} \mathrm{O}_{2}$ cathode material by tungsten oxide coating for improved electrochemical performance in lithium ion batteries. ACS Appl. Mater. Interfaces 11, 18404-18414. doi: 10.1021/acsami.9b02889

Bhuvaneswari, S., Varadaraju, U. V., Gopalan, R., and Prakash, R. (2019). Structural stability and superior electrochemical performance of Sc-doped $\mathrm{LiMn}_{2} \mathrm{O}_{4}$ spinel as cathode for lithium ion batteries. Electrochim. Acta 301, 342-351. doi: 10.1016/j.electacta.2019.01.174

Binder, J., Culver, S. P., Pinedo, R., Weber, D. A., Friedrich, M., Gries, K., et al. (2018). Investigation of fluorine and nitrogen as anionic dopants in nickelrich cathode materials for lithium-ion batteries. ACS Appl. Mater. Interfaces 10, 44452-44462. doi: 10.1021/acsami.8b16049

Chang, W., Choi, J.-W., Im, J.-C., and Lee, J. K. (2010). Effects of ZnO coating on electrochemical performance and thermal stability of $\mathrm{LiCoO}_{2}$ as cathode material for lithium-ion batteries. J. Power Sources 195, 320-326. doi: 10.1016/j.jpowsour.2009.06.104

Chen, M., Zhao, E., Chen, D., Wu, M., Han, S., Huang, Q., et al. (2017). Decreasing $\mathrm{Li} / \mathrm{Ni}$ disorder and improving the electrochemical performances of Ni-rich $\mathrm{LiNi}_{0.8} \mathrm{Co}_{0.1} \mathrm{Mn}_{0.1} \mathrm{O}_{2}$ by Ca doping. Inorg. Chem. 56, 8355-8362. doi: 10.1021/acs.inorgchem.7b01035

Chen, S., He, T., Su, Y., Lu, Y., Bao, L., Chen, L., et al. (2017). Nirich $\mathrm{LiNi}_{0.8} \mathrm{Co}_{0.1} \mathrm{Mn}_{0.1} \mathrm{O}_{2}$ oxide coated by dual-conductive layers as high performance cathode material for lithium-ion batteries. ACS Appl. Mater. Interfaces 9, 29732-29743. doi: 10.1021/acsami.7b08006

Cho, W., Lim, Y. J., Lee, S.-M., Kim, J. H., Song, J. H., Yu, J.-S., et al. (2018). Facile Mn surface doping of Ni-rich layered cathode materials for lithium ion batteries. ACS Appl. Mater. Interfaces 10, 38915-38921. doi: 10.1021/acsami.8b13766

Dai, Y., Cai, L., and White, R. E. (2012). Capacity fade model for spinel $\mathrm{LiMn}_{2} \mathrm{O}_{4}$ electrode. J. Electrochem. Soc. 160, A182-A190. doi: 10.1149/2.026302jes

Deng, T., Fan, X., Cao, L., Chen, J., Hou, S., Ji, X., et al. (2019). Designing in-situformed interphases enables highly reversible cobalt-free $\mathrm{LiNiO}_{2}$ cathode for Liion and Li-metal batteries. Joule 3, 2550-2564. doi: 10.1016/j.joule.2019.08.004

Ding, J., Lu, Z., Wu, M., Liu, C., Ji, H., and Yang, G. (2017). Preparation and performance characterization of $\mathrm{AlF}_{3}$ as interface stabilizer coated $\mathrm{Li}_{1.24} \mathrm{Ni}_{0.12}$ the traditional core-shell boundaries and effectively solves the abovementioned problems. Summarizing the method of synthesizing high-nickel NCM ternary cathode material guides the experiment. In future research, the application of first principles to build a model of synthetic materials for performance calculation can broaden the research ideas and save time and cost.

\section{AUTHOR CONTRIBUTIONS}

LS and JD wrote the manuscript. ZX, PJ, ZC, and HZ helped to revise the manuscript. All authors contributed to the article and approved the submitted version.

\section{FUNDING}

This work was financially supported by the National Natural Science Foundation of China (Nos. 21501015, 51604042, 31527803, and 21545010).

$\mathrm{Co}_{0.12} \mathrm{Mn}_{0.56} \mathrm{O}_{2}$ cathode for lithium-ion batteries. Appl. Surf. Sci. 406, 21-29. doi: 10.1016/j.apsusc.2017.02.115

Do, S. J., Santhoshkumar, P., Kang, S. H., Prasanna, K., Jo, Y. N., and Lee, C. W. (2018). Al-doped $\mathrm{Li}\left[\mathrm{Ni}_{0.78} \mathrm{Co}_{0.1} \mathrm{Mn}_{0.1} \mathrm{Al}_{0.02}\right] \mathrm{O}_{2}$ for high performance of lithium ion batteries. Ceram. Int. 45, 6972-6977. doi: 10.1016/j.ceramint.2018.12.196

Fu, C., Li, G., Luo, D., Li, Q., Fan, J., and Li, L. (2014). Nickelrich layered microspheres cathodes: lithium/nickel disordering and electrochemical performance. ACS Appl. Mater. Interfaces 6, 15822-15831. doi: 10.1021/am5030726

Gao, H., Cai, J., Xu, G.-L., Li, L., Ren, Y., and Meng, X. (2019). Surface modification for suppressing interfacial parasitic reactions of nickel-rich lithium-ion cathode. Chem. Mater. 31, 2723-2730. doi: 10.1021/acs.chemmater.8b04200

Garcia, J. C., Bareño, J., Yan, J., Chen, G., Hauser, A., Croy, J. R., et al. (2017). Surface structure, morphology, and stability of $\mathrm{Li}\left(\mathrm{Ni}_{1 / 3} \mathrm{Mn}_{1 / 3} \mathrm{Co}_{1 / 3}\right) \mathrm{O}_{2}$ cathode material. J. Phys. Chem. 121, 8290-8299. doi: 10.1021/acs.jpcc.7b 00896

Hong, J., Lim, H.-D., Lee, M., Kim, S.-W., Kim, H., and Oh, S.-T. (2012). Critical role of oxygen evolved from layered Li-excess metal oxides in lithium rechargeable batteries. Chem. Mater. 24, 2692-2697. doi: 10.1021/cm3005634

Hou, P., Li, F., Sun, Y., Li, H., Xu, X., and Zhai, T. (2018). Multishell precursors facilitated synthesis of concentration-gradient nickel-rich cathodes for longlife and high-rate lithium-ion batteries. ACS Appl. Mater. Interfaces 10, 24508-24515. doi: 10.1021/acsami.8b06286

Hou, P., Yin, J., Ding, M., Huang, J., and Xu, X. (2017). Surface/interfacial structure and chemistry of high-energy nickel-rich layered oxide cathodes: advances and perspectives. Small 13:1701802. doi: 10.1002/smll.201701802

Huang, B., Liu, D., Zhang, L., Qian, K., Zhou, K., Cai, X., et al. (2019). An efficient synthetic method to prepare high-performance Ni-rich $\mathrm{LiNi}_{0.8} \mathrm{Co}_{0.1} \mathrm{Mn}_{0.1} \mathrm{O}_{2}$ for lithium-ion batteries. ACS Appl. Energy Mater. 2, 7403-7411. doi: 10.1021/acsaem.9b01414

Jiang, Y., Liu, Z., Zhang, Y., Hu, H., Teng, X., Wang, D., et al. (2019). Fullgradient structured $\mathrm{LiNi}_{0.8} \mathrm{Co}_{0.1} \mathrm{Mn}_{0.1} \mathrm{O}_{2}$ cathode material with improved rate and cycle performance for lithium ion batteries. Electrochim. Acta 309, 74-85. doi: 10.1016/j.electacta.2019.04.058

Jin, Y., Xu, Y., Ren, F., and Ren, P. (2019). Mg-doped $\mathrm{Li}_{1.133} \mathrm{Ni}_{0.2} \mathrm{Co}_{0.2} \mathrm{Mn}_{0.467} \mathrm{O}_{2}$ in Li site as high-performance cathode material for Li-ion batteries. Solid State Ionics 336, 87-94. doi: 10.1016/j.ssi.2019.03.020

Ju, J.-W., Lee, E.-J., Yoon, C. S., Myung, S.-T., and Sun, Y.-K. (2013). Optimization of layered cathode material with full concentration gradient for lithium-ion batteries. J. Phys. Chem. C 118, 175-182. doi: 10.1021/jp4097887

Julien, C., Mauger, A., Zaghib, K., and Groult, H. (2014). Comparative issues of cathode materials for Li-ion batteries. Inorganics 2, 132-154. doi: 10.3390/inorganics2010132 
Jun, D.-W., Yoon, C. S., Kim, U.-H., and Sun, Y.-K. (2017). High-energy density core-shell structured $\mathrm{Li}\left[\mathrm{Ni}_{0.95} \mathrm{Co}_{0.025} \mathrm{Mn}_{0.025}\right] \mathrm{O}_{2}$ cathode for lithium-ion batteries. Chem. Mater. 29, 5048-5052. doi: 10.1021/acs.chemmater.7b01425

Jung, R., Morasch, R., Karayaylali, P., Phillips, K., Maglia, F., Stinner, C., et al. (2018). Effect of ambient storage on the degradation of Ni-Rich positive electrode materials (NMC811) for Li-ion batteries. J. Electrochem. Soc. 165, A132-A141. doi: 10.1149/2.0401802jes

Kang, K., and Ceder, G. (2006). Factors that affect Li mobility in layered lithium transition metal oxides. Phys. Rev. B 74:094105. doi: 10.1103/PhysRevB.74.094105

Kang, K., Meng, Y. S., Breger, J., Grey, C. P., and Ceder, G. (2006). Electrodes with high power and high capacity for rechargeable lithium batteries. Science 311, 977-980. doi: 10.1126/science.1122152

Lee, W. J., Prasanna, K., Jo, Y. N., Kim, K. J., Kim, H. S., and Lee, C. W. (2014). Depth profile studies on nickel rich cathode material surfaces after cycling with an electrolyte containing vinylene carbonate at elevated temperature. Phys. Chem. Chem. Phys. 16, 17062-17071. doi: 10.1039/C4CP02075H

Li, J., Liu, Y., Yao, W., Rao, X., Zhong, S., and Qian, L. (2020). $\mathrm{Li}_{2} \mathrm{TiO}_{3}$ and $\mathrm{Li}_{2} \mathrm{ZrO}_{3}$ co-modification $\mathrm{LiNi}_{0.8} \mathrm{Co}_{0.1} \mathrm{Mn}_{0.1} \mathrm{O}_{2}$ cathode material with improved high-voltage cycling performance for lithium-ion batteries. Solid State Ionics 349:115292. doi: 10.1016/j.ssi.2020.115292

Li, L., Song, S., Zhang, X., Chen, R., Lu, J., Wu, F., et al. (2014). Ultrasonic-assisted co-precipitation to synthesize lithium-rich cathode $\mathrm{Li}_{1.3} \mathrm{Ni}_{0.21} \mathrm{Mn}_{0.64} \mathrm{O}_{2+\mathrm{d}}$ materials for lithium-ion batteries. J. Power Sources 272, 922-928. doi: 10.1016/j.jpowsour.2014.08.063

Li, L., Xia, L., Yang, H., Zhan, X., Chen, J., Chen, Z., et al. (2020). Solid-state synthesis of lanthanum-based oxides Co-coated $\mathrm{LiNi}_{0.5} \mathrm{Co}_{0.2} \mathrm{Mn}_{0.3} \mathrm{O}_{2}$ for advanced lithium ion batteries. J. Alloys Compd. 832:154959. doi: 10.1016/j.jallcom.2020.154959

Li, Q., Dang, R., Chen, M., Lee, Y., Hu, Z., and and Xiao, X. (2018). Synthesis method for long cycle life lithium-ion cathode material: nickel-rich coreshell $\mathrm{LiNi}_{0.8} \mathrm{Co}_{0.1} \mathrm{Mn}_{0.1} \mathrm{O}_{2}$. ACS Appl. Mater. Interfaces 10, 17850-17860. doi: 10.1021 /acsami.8b02000

Li, Y., Lai, F., Zhang, X., Wang, H., Chen, Z., He, X., et al. (2019). Surface modification of Sr-doped $\mathrm{LaMnO}_{3}$ coating by spray drying on Ni-rich $\mathrm{LiNi}_{0.8} \mathrm{Mn}_{0.1} \mathrm{Co}_{0.1} \mathrm{O}_{2}$ cathode material for lithium-ion batteries. J. Taiwan Inst.Chem. Eng. 102, 225-232. doi: 10.1016/j.jtice.2019.06.006

Liang, L., Hu, G., Cao, Y., Du, K., and Peng, Z. (2015). Synthesis and characterization of full concentration-gradient $\mathrm{LiNi}_{0.7} \mathrm{Co}_{0.1} \mathrm{Mn}_{0.2} \mathrm{O}_{2}$ cathode material for lithium-ion batteries. J. Alloys Compd. 635, 92-100. doi: $10.1016 /$ j.jallcom.2015.02.032

Liao, J.-Y., and Manthiram, A. (2015). Surface-modified concentration-gradient Ni-rich layered oxide cathodes for high-energy lithium-ion batteries. J. Power Sources 282, 429-436. doi: 10.1016/j.jpowsour.2015.02.078

Liao, J.-Y., Oh, S.-M., and Manthiram, A. (2016). Core/double-shell type gradient $\mathrm{Ni}$-Rich $\mathrm{LiNi}_{0.76} \mathrm{Co}_{0.10} \mathrm{Mn}_{0.14} \mathrm{O}_{2}$ with high capacity and long cycle life for lithium-ion batteries. ACS Appl. Mater. Interfaces 8, 24543-24549. doi: $10.1021 /$ acsami.6b06172

Lin, F., Markus, I. M., Nordlund, D., Weng, T.-C., Asta, M. D., Xin, H. L., et al. (2014). Surface reconstruction and chemical evolution of stoichiometric layered cathode materials for lithium-ion batteries. Nat. Commun. 5:3529. doi: $10.1038 /$ ncomms4529

Lipu, M. S. H., Hannan, M. A., Hussain, A., Hoque, M. M., Ker, P. J., Saad, M. H. M., et al. (2018). A review of state of health and remaining useful life estimation methods for lithium-ion battery in electric vehicles: challenges and recommendations. J. Clean. Prod. 205, 115-133. doi: 10.1016/j.jclepro.2018.09.065

Liu, H., Yang, Y., and Zhang, J. (2007). Reaction mechanism and kinetics of lithium ion battery cathode material $\mathrm{LiNiO}_{2}$ with $\mathrm{CO}_{2}$. J. Power Sources 173, 556-561. doi: 10.1016/j.jpowsour.2007.04.083

Liu, L., Li, M., Chu, L., Jiang, B., Ruoxu, L., and Xiaopei, Z. (2020). Layered ternary metal oxides: performance degradation mechanisms as cathodes, and design strategies for high-performance batteries. Prog. Mater. Sci. 111:100655. doi: 10.1016/j.pmatsci.2020.100655

Liu, S., Wu, H., Huang, L., Xiang, M., Liu, H., and Zhang, Y. (2016). Synthesis of $\mathrm{Li}_{2} \mathrm{Si}_{2} \mathrm{O}_{5}$-coated $\mathrm{LiNi}_{0.6} \mathrm{Co}_{0.2} \mathrm{Mn}_{0.2} \mathrm{O}_{2}$ cathode materials with enhanced highvoltage electrochemical properties for lithium-ion batteries. J. Alloys Compd. 674, 447-454. doi: 10.1016/j.jallcom.2016.03.060
Liu, Y., Tang, L., Wei, H., Zhang, X., He, Z., Li, Y., et al. (2019). Enhancement on structural stability of Ni-rich cathode materials by in-situ fabricating dual-modified layer for lithium-ion batteries. Nano Energy 65:104043. doi: 10.1016/j.nanoen.2019.104043

Liu, Z., Zhang, Z., Liu, Y., Li, L., and Fu, S. (2019). Facile and scalable fabrication of $\mathrm{K}^{+}$-doped $\mathrm{Li}_{1.2} \mathrm{Ni}_{0.2} \mathrm{Co}_{0.08} \mathrm{Mn}_{0.52} \mathrm{O}_{2}$ cathode with ultra high capacity and enhanced cycling stability for lithium ion batteries. Solid State Ionics 332, 47-54. doi: 10.1016/j.ssi.2018.12.021

Ma, F., Wu, Y., Wei, G., Qiu, S., Qu, J., and Qi, T. (2019). Comparative study of simple and concentration gradient shell coatings with $\mathrm{Li}_{1.2} \mathrm{Ni}_{0.13} \mathrm{Mn}_{0.54} \mathrm{Co}_{0.13} \mathrm{O}_{2}$ on $\mathrm{LiNi}_{0.8} \mathrm{Mn}_{0.1} \mathrm{Co}_{0.1} \mathrm{O}_{2}$ cathodes for lithium-ion batteries. Solid State Ionics 341:115034. doi: 10.1016/j.ssi.2019.115034

Märker, K., Reeves, P. J., Xu, C., Griffith, K. J., and Grey, C. P. (2019). Evolution of structure and lithium dynamics in $\mathrm{LiNi}_{0.8} \mathrm{Mn}_{0.1} \mathrm{Co}_{0.1} \mathrm{O}_{2}$ (NMC811) cathodes during electrochemical cycling. Chem. Mater. 31, 2545-2554. doi: 10.1021/acs.chemmater.9b00140

Mossali, E., Picone, N., Gentilini, L., Rodrìguez, O., Pérez, J. M., and Colledani, M. (2020). Lithium-ion batteries towards circular economy: a literature review of opportunities and issues of recycling treatments. J. Environ. Manag. 264:110500. doi: 10.1016/j.jenvman.2020.110500

Nanthagopal, M., Santhoshkumar, P., Shaji, N., Praveen, S., Kang, H. S., and Senthil, C. (2019). Nitrogen-doped carbon-coated $\mathrm{Li}\left[\mathrm{Ni}_{0.8} \mathrm{Co}_{0.1} \mathrm{Mn}_{0.1}\right] \mathrm{O}_{2}$ cathode material for enhanced lithium-ion storage. Appl. Surf. Sci. 492, 871-878. doi: 10.1016/j.apsusc.2019.06.242

Noh, H.-J., Myung, S.-T., Lee, Y. J., and Sun, Y.-K. (2014). High-energy layered oxide cathodes with thin shells for improved surface stability. Chem. Mater. 26, 5973-5979. doi: 10.1021/cm502774u

Pant, D., and Dolker, T. (2017). Green and facile method for the recovery of spent lithium nickel manganese cobalt oxide (NMC) based lithium ion batteries. Waste Manag. 60, 689-695. doi: 10.1016/j.wasman.2016.09.039

Park, K., and Choi, B. (2018). Requirement of high lithium content in Ni-rich layered oxide material for $\mathrm{Li}$ ion batteries. J. Alloys Compd. 766, 470-476. doi: 10.1016/j.jallcom.2018.06.135

Qiu, L., Xiang, W., Tian, W., Xu, C.-L., Li, Y.-C., and Wu, Z.-G. (2019). Polyanion and cation co-doping stabilized Ni-rich Ni-Co-Al material as cathode with enhanced electrochemical performance for Li-ion battery. Nano Energy 63:103818. doi: 10.1016/j.nanoen.2019.06.014

Ren, D., Shen, Y., Yang, Y., Shen, L., Levin, B. D. A., Yu, Y., et al. (2017). Systematic optimization of battery materials: key parameter optimization for the scalable synthesis of uniform, high-energy, and high stability $\mathrm{LiNi}_{0.6} \mathrm{Mn}_{0.2} \mathrm{Co}_{0.2} \mathrm{O}_{2}$ cathode material for lithium-ion batteries. ACS Appl. Mater. Interfaces 9, 35811-35819. doi: 10.1021/acsami.7b10155

Seteni, B., Rapulenyane, N., Ngila, J. C., Mpelane, S., and Luo, H. (2017). Coating effect of $\mathrm{LiFePO}_{4}$ and $\mathrm{Al}_{2} \mathrm{O}_{3}$ on $\mathrm{Li}_{1.2} \mathrm{Mn}_{0.54} \mathrm{Ni}_{0.13} \mathrm{Co}_{0.13} \mathrm{O}_{2}$ cathode surface for lithium ion batteries. J. Power Sources 353, 210-220. doi: 10.1016/j.jpowsour.2017.04.008

Shi, H., Wang, X., Hou, P., Zhou, E., Guo, J., Zhang, J., et al. (2014). Core-shell structured $\mathrm{Li}\left[\left(\mathrm{Ni}_{0.8} \mathrm{Co}_{0.1} \mathrm{Mn}_{0.1}\right)_{0.7}\left(\mathrm{Ni}_{0.45} \mathrm{Co}_{0.1} \mathrm{Mn}_{0.45}\right)_{0.3}\right] \mathrm{O}_{2}$ cathode material for high-energy lithium ion batteries. J. Alloys Compd. 587, 710-716. doi: 10.1016/j.jallcom.2013.10.226

Sivaprakash, S., and Majumder, S. B. (2009). Understanding the role of $\mathrm{Zr}^{4+}$ cation in improving the cycleability of $\mathrm{LiNi}_{0.8} \mathrm{Co}_{0.15} \mathrm{Zr}_{0.05} \mathrm{O}_{2}$ cathodes for Li ion rechargeable batteries. J. Alloys Compd. 479, 561-568. doi: 10.1016/j.jallcom.2008.12.129

Song, D., Hou, P., Wang, X., Shi, X., and Zhang, L. (2015). Understanding the origin of enhanced performances in core-shell and concentration-gradient layered oxide cathode materials. ACS Appl. Mater. Interfaces 7, 12864-12872. doi: 10.1021/acsami.5b02373

Su, Y., Chen, G., Chen, L., Lu, Y., Zhang, Q., Lv, Z., et al. (2019). High-rate structure-gradient Ni-rich cathode material for lithium-ion batteries. ACS Appl. Mater.Interfaces 11, 36697-36704. doi: 10.1021/acsami.9b12113

Sun, Y.-K., Myung, S.-T., Kim, M.-H., Prakash, J., and Amine, K. (2005). Synthesis and characterization of $\operatorname{Li}\left[\left(\mathrm{Ni}_{0.8} \mathrm{Co}_{0.1} \mathrm{Mn}_{0.1}\right)_{0.8}\left(\mathrm{Ni}_{0.5} \mathrm{Mn}_{0.5}\right)_{0.2}\right] \mathrm{O}_{2}$ with the microscale core-shell structure as the positive electrode material for lithium batteries. J. Am. Chem. Soc.127, 13411-13418. doi: 10.1021/ja05 $3675 \mathrm{~g}$

Sun, Y.-K., Myung, S.-T., Park, B.-C., and Amine, K. (2006a). Synthesis of spherical nano- to microscale core-shell particles 
$\mathrm{Li}\left[\left(\mathrm{Ni}_{0.8} \mathrm{Co}_{0.1} \mathrm{Mn}_{0.1}\right)_{1-\mathrm{x}}\left(\mathrm{Ni}_{0.5} \mathrm{Mn}_{0.5}\right)_{\mathrm{X}}\right] \mathrm{O}_{2}$ and their applications to lithium batteries. Chem. Mater. 18, 5159-5163. doi: 10.1021/cm061746k

Sun, Y.-K., Myung, S.-T., Shin, H.-S., Bae, Y. C., and Yoon, C. S. (2006b). Novel core-shell-structured $\mathrm{Li}\left[\left(\mathrm{Ni}_{0.8} \mathrm{Co}_{0.2}\right)_{0.8}\left(\mathrm{Ni}_{0.5} \mathrm{Mn}_{0.5}\right)_{0.2}\right] \mathrm{O}_{2}$ via coprecipitation as positive electrode material for lithium secondary batteries. J. Phys. Chem. B 110, 6810-6815. doi: 10.1021/jp0571473

Tian, J., Su, Y., Wu, F., Xu, S., Chen, F., Chen, R., et al. (2015). High-rate and cycling-stable nickel-rich cathode materials with enhanced $\mathrm{Li}^{+}$diffusion pathway. ACS Appl. Mater. Interfaces 8, 582-587. doi: 10.1021/acsami.5b09641

Trease, N. M., Seymour, I. D., Radin, M. D., Liu, H., Liu, H., and Hy, S. (2016). Identifying the distribution of $\mathrm{Al}^{3+}$ in $\mathrm{LiNi}_{0.8} \mathrm{Co}_{0.15} \mathrm{Al}_{0.05} \mathrm{O}_{2}$. Chem. Mater. 28, 8170-8180. doi: 10.1021/acs.chemmater.6b02797

Van der Ven, A., and Ceder, G. (2001). Lithium diffusion mechanisms in layered intercalation compounds. J. Power Sources 97-98, 529-531. doi: $10.1016 / 50378-7753(01) 00638-3$

Van Ree, T. (2020). Electrolyte additives for improved lithium-ion battery performance and overcharge protection. Curr. Opin. Electrochem. 21, 22-30. doi: 10.1016/j.coelec.2020.01.001

Wang, H. B., Du, Z., Rui, X. Y., Wang, S. Y., Jin, C. Y., He, L., et al. (2020a). A comparative analysis on thermal runaway behavior of $\mathrm{Li}\left(\mathrm{Ni}_{\mathrm{X}} \mathrm{Co}_{\mathrm{y}} \mathrm{Mn}_{\mathrm{z}}\right) \mathrm{O}_{2}$ battery with different nickel contents at cell and module level. J. Hazard. Mater. 393:122361. doi: 10.1016/j.jhazmat.2020.122361

Wang, K., Wan, J., Xiang, Y., Zhu, J., Leng, Q., and Wang, M. (2020b). Recent advances and historical developments of high voltage lithium cobalt oxide materials for rechargeable Li-ion batteries. J. Power Sources 460:228062. doi: 10.1016/j.jpowsour.2020.228062

Wang, Q., Shen, C.-H., Shen, S.-Y., Xu, Y.-F., Shi, C.-G., Huang, L., et al. (2017). Origin of structural evolution in capacity degradation for overcharged NMC622 via operando coupled investigation. ACS Appl. Mater. Interfaces 9, 24731-24742. doi: 10.1021/acsami.7b06326

Wang, R., Dai, X., Qian, Z., Sun, Y., Fan, S., and Xiong, K. (2020c). In-situ surface protection for enhancing stability and performance of $\mathrm{LiNi}_{0.5} \mathrm{Mn}_{0.3} \mathrm{Co}_{0.2} \mathrm{O}_{2}$ at $4.8 \mathrm{~V}$ : the working mechanisms. ACS Mater. Lett. 2, 280-290. doi: 10.1021/acsmaterialslett.9b00476

Wang, R., Dai, X., Qian, Z., Zhong, S., Chen, S., and Fan, S. (2020d). Boosting lithium storage in free-standing black phosphorus anode via multifunction of nanocellulose. ACS Appl. Mater. Interfaces 12, 31628-31636. doi: 10.1021/acsami.0c08346

Wang, R., Sun, Y., Yang, K., Zheng, J., Li, Y., and Qian, Z. (2020e). One-time sintering process to modify $\mathrm{xLi}_{2} \mathrm{MnO}_{3}(1-\mathrm{x}) \mathrm{LiMO}_{2}$ hollow architecture and studying their enhanced electrochemical performances. J. Energ. Chem. 50, 271-279. doi: 10.1016/j.jechem.2020.03.042

Wang, W., Yang, S., Lin, C., Shen, W., Lu, G., Li, Y., et al. (2020f). Investigation of mechanical property of cylindrical lithium-ion batteries under dynamic loadings. J. Power Sources 451:227749. doi: 10.1016/j.jpowsour.2020.227749

Woo, S.-W., Myung, S.-T., Bang, H., Kim, D.-W., and Sun, Y.-K. (2009). Improvement of electrochemical and thermal properties of $\mathrm{Li}\left[\mathrm{Ni}_{0.8} \mathrm{Co}_{0.1} \mathrm{Mn}_{0.1}\right] \mathrm{O}_{2}$ positive electrode materials by multiple metal ( $\mathrm{Al}, \mathrm{Mg})$ substitution. Electrochim. Acta 54, 3851-3856. doi: 10.1016/j.electacta.2009.01.048

Wu, Y., Li, M., Wahyudi, W., Sheng, G., Miao, X., Anthopoulos, T. D., et al. (2019). Performance and stability improvement of layered NCM lithium-ion batteries at high voltage by a microporous $\mathrm{Al}_{2} \mathrm{O}_{3}$ sol-gel coating. ACS Omega 4, 13972-13980. doi: 10.1021/acsomega.9b01706

Xu, Y., Liu, Y., Lu, Z., Wang, H., Sun, D., and Yang, G. (2016). The preparation and role of $\mathrm{Li}_{2} \mathrm{ZrO}_{3}$ surface coating $\mathrm{LiNi}_{0.5} \mathrm{Co}_{0.2} \mathrm{Mn}_{0.3} \mathrm{O}_{2}$ as cathode for lithium-ion batteries. Appl. Surf. Sci. 361, 150-156. doi: 10.1016/j.apsusc.2015.11.156

Xue, L., Li, Y., Xu, B., Chen, Y., Cao, G., and Li, J. (2018). Effect of Mo doping on the structure and electrochemical performances of $\mathrm{LiNi}_{0.6} \mathrm{Co}_{0.2} \mathrm{Mn}_{0.2} \mathrm{O}_{2}$ cathode material at high cut-off voltage. J. Alloys Compd. 748, 561-568. doi: 10.1016/j.jallcom.2018.03.192

Yan, P., Zheng, J., Zhang, X., Xu, R., Amine, K., Xiao, J., et al. (2016). Atomic to nanoscale investigation of functionalities of an $\mathrm{Al}_{2} \mathrm{O}_{3}$ coating layer on a cathode for enhanced battery performance. Chem. Mater. 28, 857-863. doi: 10.1021/acs.chemmater.5b04301

Yang, Q., Huang, J., Li, Y., Wang, Y., Qiu, J., and Zhang, J. (2018). Surfaceprotected $\mathrm{LiCoO}_{2}$ with ultrathin solid oxide electrolyte film for high-voltage lithium ion batteries and lithium polymer batteries. J. Power Sources 388, 65-70. doi: 10.1016/j.jpowsour.2018.03.076

Yang, X., Tang, Y., Qu, Y., Shang, G., Wu, J., Zheng, J., et al. (2019a). Bifunctional nano- $\mathrm{ZrO}_{2}$ modification of $\mathrm{LiNi}_{0.92} \mathrm{Co}_{0.08} \mathrm{O}_{2}$ cathode enabling high-energy density lithium ion batteries. J. Power Sources 438:226978. doi: 10.1016/j.jpowsour.2019.226978

Yang, X., Tang, Y., Zheng, J., Shang, G., Wu, J., Lai, Y., et al. (2019b). Tailoring structure of Ni-rich layered cathode enable robust calendar life and ultrahigh rate capability for lithium-ion batteries. Electrochim. Acta 320:134587. doi: 10.1016/j.electacta.2019.134587

Yoon, W.-S., Nam, K.-W., Jang, D., Chung, K. Y., Hanson, J., Chen, J.-M., et al (2012). Structural study of the coating effect on the thermal stability of charged $\mathrm{MgO}$-coated $\mathrm{LiNi}_{0.8} \mathrm{Co}_{0.2} \mathrm{O}_{2}$ cathodes investigated by in situ XRD. J. Power Sources 217, 128-134. doi: 10.1016/j.jpowsour.2012.05.028

Yu, Y., Yang, Z., Zhong, J., Liu, Y., Li, J., Wang, X., et al. (2020). A simple dual-ion doping method to stabilize $\mathrm{Li}$-Rich materials and suppress voltage decay. ACS Appl. Mater. Interfaces 12, 13996-14004. doi: 10.1021/acsami.0c00944

Zhang, D., Liu, Y., Wu, L., Feng, L., Jin, S., and Zhang, R. (2019). Effect of $\mathrm{Ti}$ ion doping on electrochemical performance of Ni-rich $\mathrm{LiNi}_{0.8} \mathrm{Co}_{0.1} \mathrm{Mn}_{0.1} \mathrm{O}_{2}$ cathode material. Electrochim. Acta 328:135086. doi: 10.1016/j.electacta.2019.135086

Zhang, Q., Wang, D., Yang, B., Cui, X., and Li, X. (2020). Electrochemical model of lithium-ion battery for wide frequency range applications. Electrochim. Acta 343:136094. doi: 10.1016/j.electacta.2020.136094

Zhang, X., Chen, Z., Schwarz, B., Sigel, F., Ehrenberg, H., An, K., et al. (2017). Kinetic characteristics up to $4.8 \mathrm{~V}$ of layered $\mathrm{LiNi}_{1 / 3} \mathrm{Co}_{1 / 3} \mathrm{Mn}_{1 / 3} \mathrm{O}_{2}$ cathode materials for high voltage lithium-ion batteries. Electrochim. Acta 227, 152-161. doi: 10.1016/j.electacta.2017.01.014

Zhang, X.-Q., Zhao, C.-Z., Huang, J.-Q., and Zhang, Q. (2018). Recent advances in energy chemical engineering of next-generation lithium batteries. Engineering 4, 831-847. doi: 10.1016/j.eng.2018.10.008

Zhao, R., Liang, J., Huang, J., Zeng, R., Zhang, J., Chen, H., et al. (2017). Improving the Ni-rich $\mathrm{LiNi}_{0.5} \mathrm{Co}_{0.2} \mathrm{Mn}_{0.3} \mathrm{O}_{2}$ cathode properties at high operating voltage by double coating layer of $\mathrm{Al}_{2} \mathrm{O}_{3}$ and $\mathrm{AlPO}_{4}$. J. Alloys Compd. 724, 1109-1116. doi: 10.1016/j.jallcom.2017.05.331

Zhao, W., Zhong, G., McDonald, M. J., Gong, Z., Liu, R., Bai, J., et al. (2016). $\mathrm{Cu}_{3}\left(\mathrm{PO}_{4}\right)_{2} / \mathrm{C}$ composite as a high-capacity cathode material for rechargeable Na-ion batteries. Nano Energy 27, 420-429. doi: 10.1016/j.nanoen.2016. 07.011

Zhao, Z. Y., Huang, B., Wang, M., Yang, X. W., Gu, Y. J., et al. (2019). Facile synthesis of fluorine doped single crystal Ni-rich cathode material for lithiumion batteries. Solid State Ionics 342:115065. doi: 10.1016/j.ssi.2019.115065

Zheng, Y., Hao, X., Niu, J., and Pan, B. (2016). Layered o- $\mathrm{LiMnO}_{2}$ prepared for lithium ion batteries by mechanical alloying. Mater. Lett. 163, 98-101. doi: 10.1016/j.matlet.2015.10.042

Zhou, H., Li, Y., Zhang, J., Kang, W., and Yu, D. Y. W. (2016). Low-temperature direct synthesis of layered $\mathrm{m}-\mathrm{LiMnO}_{2}$ for lithium-ion battery applications. J. Alloys Compd. 659, 248-254. doi: 10.1016/j.jallcom.2015.11.038

Zhu, H., Shen, R., Tang, Y., Yan, X., Liu, J., and Song, L. (2020). Sndoping and $\mathrm{Li}_{2} \mathrm{SnO}_{3}$ nano-coating layer co-modified $\mathrm{LiNi}_{0.5} \mathrm{Co}_{0.2} \mathrm{Mn}_{0.3} \mathrm{O}_{2}$ with improved cycle stability at $4.6 \mathrm{~V}$ cut-off voltage. Nanomaterials 10:868. doi: 10.3390/nano10050868

Zubi, G., Dufo-López, R., Carvalho, M., and Pasaoglu, G. (2018). The lithium-ion battery: state of the art and future perspectives. Renew. Sust. Energy Rev. 89, 292-308. doi: 10.1016/j.rser.2018.03.002

Conflict of Interest: The authors declare that the research was conducted in the absence of any commercial or financial relationships that could be construed as a potential conflict of interest.

Copyright $\odot 2020$ Song, Du, Xiao, Jiang, Cao and Zhu. This is an open-access article distributed under the terms of the Creative Commons Attribution License (CC BY). The use, distribution or reproduction in other forums is permitted, provided the original author(s) and the copyright owner(s) are credited and that the original publication in this journal is cited, in accordance with accepted academic practice. No use, distribution or reproduction is permitted which does not comply with these terms. 